\title{
GEN İFADE PROGRAMLAMA İLE GÖKSU NEHRİ'NİN AKIM TAHMİNİ
}

\author{
Özlem TERZİ, Onur ÖZCANOĞLU
}

Süleyman Demirel Üniversitesi, Teknoloji Fakültesi, İnşaat Mühendisliği Bölümü, Isparta, Türkiye

\begin{tabular}{|c|c|}
\hline Anahtar Kelimeler & Özet \\
\hline $\begin{array}{l}\text { Gen İfade Programlama, } \\
\text { Günlük akım, } \\
\text { Göksu Nehri, } \\
\text { Doğu Akdeniz Havzası, } \\
\text { Akım Tahmini. }\end{array}$ & $\begin{array}{l}\text { Bu çalışmada, Gen İfade Programlama (GEP) yöntemi kullanılarak Doğu Akdeniz } \\
\text { havzasında bulunan Göksu Nehri'nin akım tahmini yapılmıştır. Akım tahmini için } \\
\text { Göksu Nehri'nde bulunan Bucakkışla, Karahacılı, Kırkkavak, Hamam, Yeşilköy ve } \\
\text { Gravga akım gözlem istasyonlarından 2006-2010 yıllarına ait günlük akım } \\
\text { değerleri kullanılarak modeller geliştirilmiştir. Karahacılı istasyonuna ait modeller } \\
\text { geliştirilirken diğer istasyonların akım değerleri ve Karahacllı istasyonunun önceki } \\
\text { günlerine ait akım değerleri girdi kullanılarak çeşitli kombinasyonlar denenmiştir. } \\
\text { Modellerin performansları değerlendirildiğinde, akım tahmininde GEP yönteminin } \\
\text { başarılı sonuçlar verdiği görülmüştür. }\end{array}$ \\
\hline
\end{tabular}

\section{STREAMFLOW ESTIMATION OF GÖKSU RIVER WITH GENE EXPRESSION PROGRAMMING}

\begin{tabular}{ll}
\hline Keywords & Abstract \\
\hline Gene Expression & In this study, Gene Expression Programming (GEP) technique was used to forecast \\
Programming, & the river flow of Göksu River, located in Doğu Akdeniz Basin. Various models were \\
Daily flow, & developed using the daily river flow data of Bucakkışla, Karahacil, Kırkkavak, \\
Göksu River, & Hamam, Yeşilköy and Gravga stations, located on Göksu River, for the period of \\
Eastern Mediterranean Basin, & $\begin{array}{l}\text { 2006-2010. While the models of Karahacll station were developed, several } \\
\text { Streamflow estimation. }\end{array}$ \\
$\begin{array}{l}\text { combinations were tried using the flow data of other stations and also the previous } \\
\text { flow data of Karahacilı station as input. When the performances of the models are } \\
\text { evaluated, it is seen that GEP is a successful method in the forecast of river flow. }\end{array}$
\end{tabular}

\begin{tabular}{|c|c|}
\hline Alıntı / Cite & \\
\hline $\begin{array}{l}\text { Terzi, Ö., Özcanoğlu, O., (2017), } \\
\text { Engineering Sciences and Design, } 5\end{array}$ & $\begin{array}{l}\text { ade Progran } \\
3-488 .\end{array}$ \\
\hline Yazar Kimliği / Author ID (ORCID & (ber) \\
\hline 0. Terzi, 0000-0001-6429-5176 & \\
\hline O. Ozcanoglu, 0000-0001-6221-491 & \\
\hline Başvuru Tarihi /Submission Date & 24.07 .2017 \\
\hline Revizyon Tarihi / Revision Date & 21.08.2017 \\
\hline Kabul Tarihi / Accepted Date & 12.09.2017 \\
\hline Yayım Tarihi / Published Date & 18.12.2017 \\
\hline
\end{tabular}

\footnotetext{
* ilgili yazar: ozlemterzi@sdu.edu.tr, +90-246-211-8001
} 


\section{Giriş}

Günümüzde, ölçüm yapllamayan yerlerdeki nehir akımlarının tahmini araştırmacıların sıklıkla karşılaştığı problemlerden biridir. Özellikle su kaynaklarının planlanması ve projelendirilmesi aşamasında, güvenilir akım tahminlerinin yapılması büyük önem taşımaktadır. Akarsularda akım, Devlet $\mathrm{Su}$ İşleri (DSİ) tarafından akarsuyun belirli noktalarında kurulan ölçüm istasyonları ile belirlenmektedir. Ancak, herhangi bir nedenle veri elde edilememesi durumunda ve dolayısıyla ölçüm olmayan yerlerde günlük ve aylık akımların tahmini için çeşitli yöntemlerin kullanılmasına ihtiyaç duyulmaktadır (Yılmaz, 2014).

Doğrusal olmayan problemlerin ele alınmasında etkin olarak kullanılan ve başarılı sonuçlar veren ve 2001 yılında Ferreira tarafından geliştirilen gen ifade programlama (GEP) bu yöntemlerden biridir. Günümüzde su kaynakları problemlerinde bu yöntemi kullanan çeşitli araştırmalar mevcuttur (Nourani vd., 2012; Fernando vd., 2012; Shoaib vd., 2015; Shiri vd. 2014).

$\mathrm{Bu}$ çalışmada, genetik algoritma ve genetik programlamanın geliştirilmesi ile elde edilen GEP yöntemi kullanılarak Göksu Nehri'ne ait akımların tahmini için çeşitli modeller geliştirilmiştir. Bunun için Akdeniz Bölgesi'nde yer alan Göksu Nehri üzerinde bulunan altı adet akım gözlem istasyonuna ait akım değerleri kullanılmıştır. En başarılı GEP modeline ait matematiksel formül elde edilmiştir.

\section{Bilimsel Yazın Taraması}

Aytek ve Kişi (2008) günlük sediment-debi ilişkisini çlkarmak için genetik programlama (GP) kullanmışlardır. Anahtar eğrisi ve çoklu lineer regresyon (ÇLR) yöntemi ile geliştirdikleri GP formülünü kıyaslamışlardır. GP formülünün iyi sonuçlar verdiğini ve kullanımının pratik olduğunu belirtmișlerdir. Shiri ve Kisi (2011) GP ile adaptif sinirsel bulanı çıkarım sistem (ANFIS) yöntemlerinin yeraltı su seviyesi tahminindeki kullanılabilirliğini incelemişlerdir. ABD'deki Bondville ve Perry istasyonlarına ait yeraltı su seviyesi verilerini kullanarak bir, iki ve üç gün sonraki yeraltı su seviyelerini tahmin edecek şekilde 5 farklı model geliştirmişlerdir. GP ve ANFIS yöntemlerinin başarılı sonuçlar verdiğini ve yeraltı su seviyesi tahmininde kullanılabileceğini, ancak GP yönteminin formülleri açık bir şekilde verdiği için daha üstün olduğunu vurgulamışlardır. Azamathulla vd. (2011) Malezya'da bulunan Pahang Nehri'nin seviye-debi ilişkisini tahmin etmek için GP'nin devamı olan GEP yöntemini alternatif bir yöntem olarak sunmuşlardır. Elde ettikleri sonuçları daha geleneksel yöntemler olan anahtar eğrisi ve regresyon teknikleri ile de kıyaslamışlardır. GEP modelinin performansının GP ve diğer geleneksel yöntemlere göre çok daha iyi olduğunu belirlemişlerdir. Traore ve Guven (2013) Kuzey Afrika'da yer alan Burkino Faso'daki tropik ve kurak bölgelerdeki evapotranspirasyon miktarını modellemek için GEP yönteminden yararlanmışlardır. Evapotranspirasyon tahmininde birçok meteorolojik veri kombinasyonu kullanmışlar ve performans değerlendirmesi için determinasyon katsayısı $\left(\mathrm{R}^{2}\right)$ ve karekök ortalama hata (KOH) değerlerini kıyaslamışladır. Çalışmada elde ettikleri sonuçlarda, GEP modelinin $0.979 \mathrm{R}^{2}$ ve $0.108 \mathrm{KOH}$ ile başarılı bir yaklaşım elde ettiğini belirtmişlerdir. Kisi vd. (2013) Orta Sakarya havzasının bir alt havzası olan Kurukavak havzasındaki yağıș-akış sürecini modellemek için 1987-1991 yıllarına ait ölçülmüş yağış ve akış verilerini kullanmışlardır. Yapay Sinir Ağları (YSA), ANFIS ve GEP yöntemlerini kullanarak geliştirdikleri modellerde değişik girdi kombinasyonlarını denemişler ve geleneksel ÇLR modeli ile de kıyaslama yapmışlardır. Çalışma sonuçlarına göre GEP yönteminin yağış-akış sürecini modellemede kullanılabileceği ve diğer yapay zekâ yöntemleri ile geleneksel yöntemlere göre geçerli bir alternatif olduğu belirtilmiştir.

\section{Materyal ve Yöntem}

\section{1. Çalışma Bölgesi ve Veriler}

Konya, Karaman, Antalya ve Mersin il sinırları içerisinde bulunan $260 \mathrm{~km}$ uzunluğa sahip Göksu Nehri, Akdeniz'e dökülmektedir. Kaynağı Toros Dağları'nda bulunan Geyik Dağları olan nehrin Gökçay ve Gökdere olmak üzere kuzey ve güney kolları mevcuttur. Ermenek'ten sonra Mut'un güneyinde birleşen bu iki kol Göksu adını alarak Taşucu ile Silifke arasında Akdeniz'e dökülmektedir. (http://tr.wikipedia.org/wiki/Göksu_(Kilikya)).

Çalışma bölgesi Şekil 1'de verilmiş olup, çalıșmada kullanılan akım gözlem istasyonları şekil üzerinde kırmızı çerçeveler ile işaretlenmiştir. 


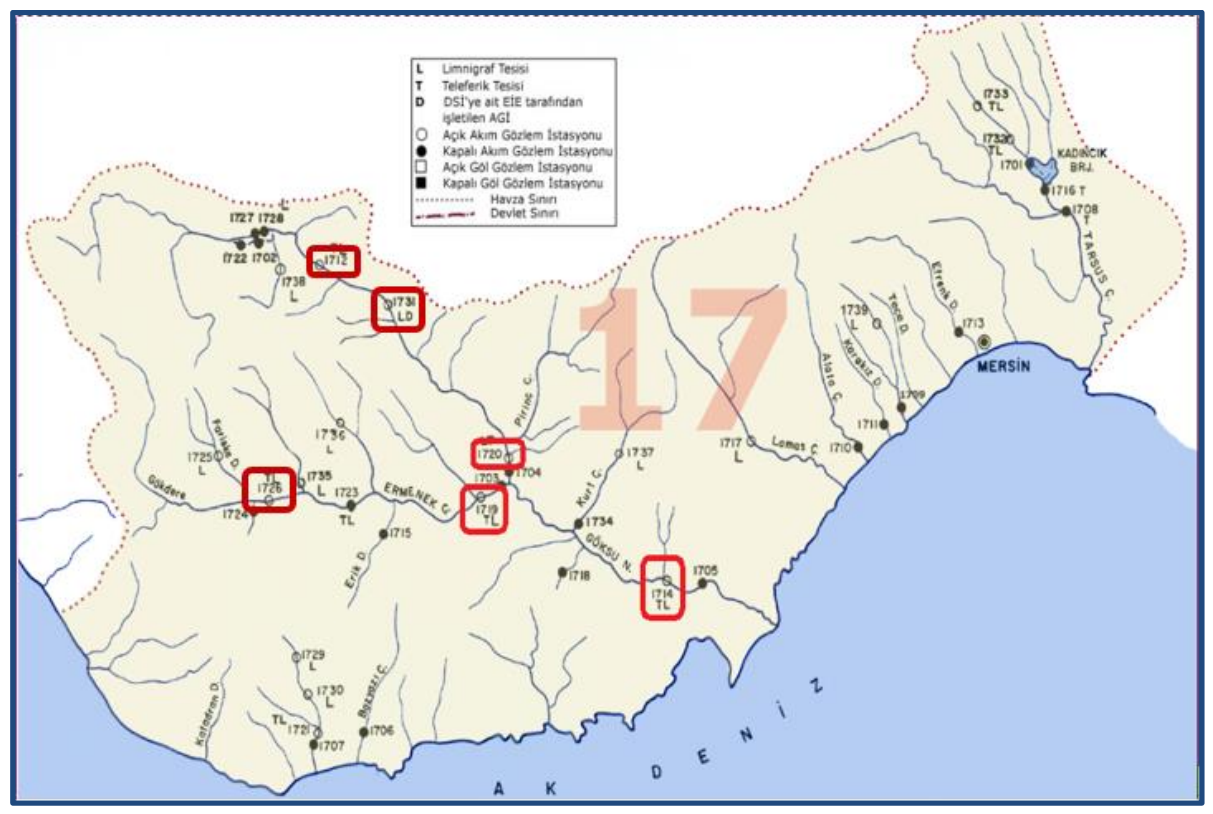

Şekil 1. Göksu Nehri havzası ve çalışmada kullanılan akım gözlem istasyonları

Modeller geliștirilirken, Elektrik İșleri Etüt İdaresi (EIE)'nden Göksu Nehri üzerinde bulunan Bucakkışla (1712), Karahacılı (1714), Kırkkavak (1719), Hamam (1720), Yeşilköy (1726) ve Gravga (1731) akım gözlem istasyonları için 2006-2010 yıllarına ait toplam 1826 adet günlük akım değerleri alınmıștır. İlk dört yıllık veri model geliştirmek için eğitim setine (\% 80), kalan bir yll ise modellerin uygunluğunu belirlemek için test setine (\% 20) ayrılmıştır.

\subsection{Gen İfade Programlama (GEP)}

Matematiksel ifade, karar ağacı, polinom yapı ve mantıksal ifade gibi bilgisayar programlarını içeren bir arama tekniği olan Genetik Programlama (GP) ilk olarak Koza tarafından 1992 yllında önerilmiștir (Goldberg, 1989). Genetik algoritmalar (GA) genelleştirilerek elde edilmiş olan GP, problemin yapısına uygun fonksiyon ve terminalleri (girdi) içeren bilgisayar programlarının popülasyonuyla işleme başlar. Gen ifade programlama da (GEP), GA ve GP gibi bireylerin popülasyonlarını kullanarak uygunluklarına göre seçim yapar. Genetik varyasyonu bir ya da birden fazla genetik operatör kullanarak tanıttığı için genetik algoritmaya benzemektedir (Aytek ve Kişi, 2008). Bu üç algoritma arasındaki asıl fark bireylerin doğasından kaynaklanmaktadır. GP'de bireyler farklı boyutlarda ve şekillerde (potansiyel çözümleri temsil eden kromozomlar) doğrusal olmayan varlıklar iken, GA'da, sabit uzunlukta (kromozomlar) olan doğrusal dizelerdir. Amaç fonksiyonuna göre, her bir varlık farklı uygunlukları sergiler. Aynı zamanda, doğrusal olmayan varlıklar, diyagramlar veya ağaçlar şeklinde temsil edilebilirler. GEP'de ise bireyler, farklı şekillerde (basit diyagram gösterimleri veya ifade ağaçları) ve boyutlarda doğrusal olmayan varlıklar olarak ifade edilen sabit uzunlukta (kromozomlar) doğrusal dizeler olarak kodlanmıştır (Ferreira, 2001).
Genetik programlama kullanılarak bir problemin çözümünde beș temel adım mevcuttur. İlki, bilgisayar programlarında kullanılmak üzere, popülasyonda terminal (girdi) setini tespit etmektir. İkinci adım ise, fonksiyonları belirlemektir. Fonksiyon setinde, aritmetik operatörler $(*, /, \quad-,+)$, matematiksel fonksiyonlar (sin, cos, log), mantıksal ifadeler (eğerdaha sonra-başka) ve boolean operatörleri (ve, ya da, yoksa) veya kullanıcının tanımlandığı başka fonksiyonlar bulunur. Popülasyondaki bilgisayar programlarının oluşturulmasını sağlayan unsurlar, terminaller ve fonksiyonlardır. Üçüncü adım, mevcut problemin çözümünde bilgisayar programının başarı seviyesini değerlendirme şeklini belirlemektir. Sayısal parametrelerin ve nitel değişkenlerin değerlerinin verildiği kontrol parametrelerinin olduğu dördüncü adımda ise, çalışma aşaması kontrol edilir. Son adımda, çalışmanın sonlandırıldığı ve sonuç tayininin yapıldığı bir kriter belirlenir (Koza, 1992).

Şematik olarak GEP'in bu önemli adımları Şekil 2'de verilmiştir. Belli bir sayıda bireyin kromozomlarının rastgele üretilmesi ile işlem başlamaktadır. Sonra bu kromozomlar ifade edilir ve her bir bireyin uygunluğu, fitness kümesi ile değerlendirilmektedir. Yeni özellikleri ile üremek ve modifikasyon ile yeniden oluşmak için bireyler uygunluklarına göre seçilir. Aynı gelişme sürecine, yeni bireyler de tabi tutulur. İfade genomları, seçim ortamının kıyaslanması, modifikasyon ve seçim ile üremedir. İyi bir çözüm bulunana kadar veya belli bir sayıda işlem yinelenir (Ferreira, 2006). 


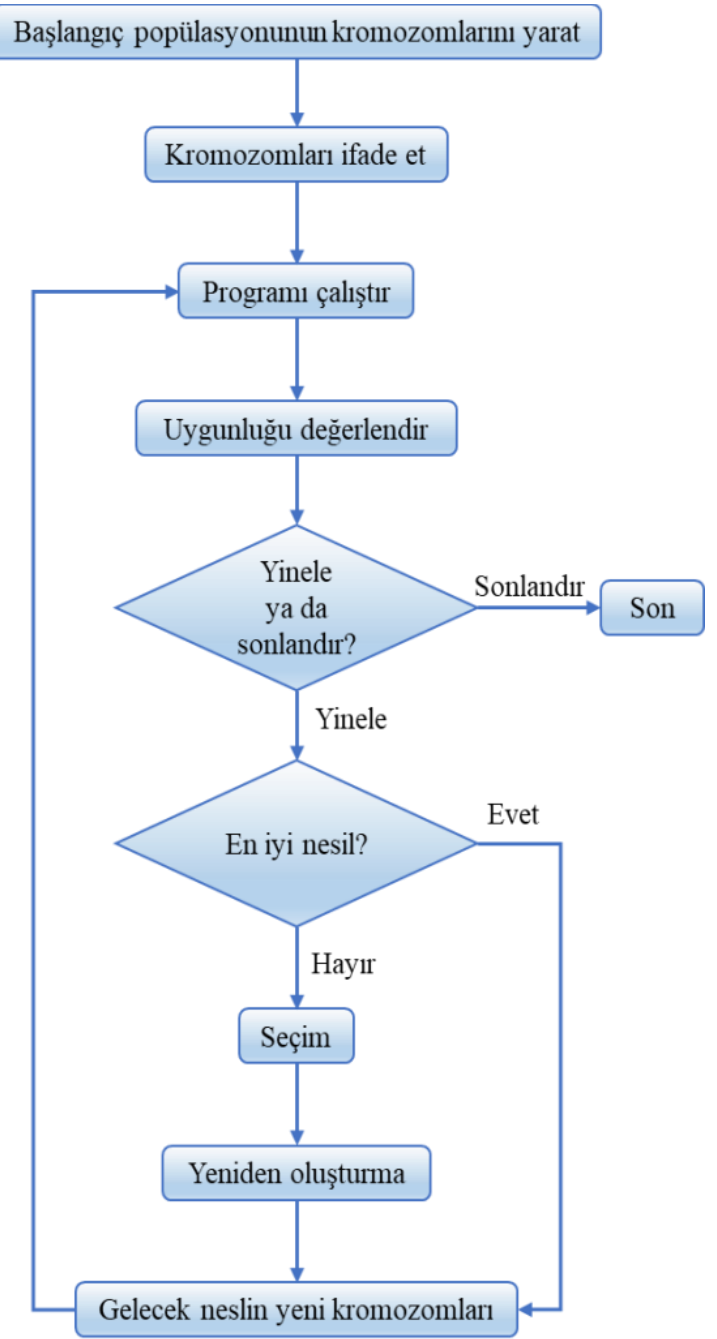

Şekil 2. Bir gen ifade algoritmasının akıș șeması (Ferreira, 2006)

İfade ağaçlarına dönüştürülen doğrusal kromozomlarda, GEP'in bireyleri kodlanmıştır. Böylece, GEP'de doğrusal kromozomlar ve ifade ağaçları hem yapısal hem de işlevsel olarak birlikte çalışan farklı varlıklar olmuştur. GEP, kromozomlar ve kromozomlarda kodlanan genetik bilgiyi gösteren ifade ağaçları olmak üzere iki temel kısımdan oluşmaktadır (Grosan ve Abraham, 2006).

\section{Araştırma Bulguları}

Göksu Nehri'ne ait akım tahmin modelleri geliştirmek için havzada bulunan altı adet akım gözlem istasyonunun akım değerleri ile GEP yöntemi kullanılmıștır. Akım tahmin modellerinde, havzanın çıkış noktasına en yakın istasyon olan Karahacılı istasyonunun günlük akım değerleri çıktı olarak alınmıştır. GEP modelleri geliştirilirken determinasyon katsayısı $\left(\mathrm{R}^{2}\right)$ ve karekök ortalama hata $(\mathrm{KOH})$ değerleri uygunluk fonksiyonu olarak seçilmiştir. Terminal (T) setinde bağımsız değişkenlerden oluşan akım miktarları kullanılırken, fonksiyon setinde ise, aritmetik operatörler $(*, /,-,+)$ ve bazı matematiksel fonksiyonlar $(\sqrt{ }, \wedge, \ln , 10 \mathrm{x}, \log )$ kullanılmıştır. Kromozom mimarisi, gen sayısı 3 ve başlık uzunluğu 8 olacak şekilde belirlenmiştir. Bağlantı fonksiyon türü olarak toplam (+) seçilmiştir. Ayrıca, modellerde kullanılan genetik operatörler seti Tablo 1'de verilmiştir.

Tablo 1. GEP modeli parametreleri

\begin{tabular}{lc}
\hline Gen sayısı & 3 \\
Başlık uzunluğu & 8 \\
Kromozom sayısı & 50 \\
Bağlantı fonksiyonu & + \\
Mutasyon oranı & 0,044 \\
Tek noktada rekombinasyon oranı & 0,3 \\
İki noktada rekombinasyon oranı & 0,3 \\
Gen rekombinasyon oranı & 0,1 \\
Gen aktarım hızı & 0,1
\end{tabular}

Çalışmada geliștirilen GEP modellerinin eğitim ve test setlerine ait $\mathrm{KOH}$ ve $\mathrm{R}^{2}$ değerleri Tablo 2'de verilmiştir. Tablo 2 incelendiğinde, aynı istasyonun önceki günlere ait akım değerleri kullanılarak geliştirilen modellerin $\mathrm{R}^{2}$ değerleri, diğer istasyonların verileri kullanılarak geliştirilen modellerden daha yüksek bulunmuştur. Buna göre, geliştirilen modeller arasından $\mathrm{Q}_{\mathrm{t}-1}$ ve $\mathrm{Q}_{\mathrm{t}-2}$ verilerinin girdi olarak kullanıldığı model 7'nin diğerlerine göre daha iyi sonuç verdiği görülmüștür. $\mathrm{Bu}$ modelin eğitim setine ait $\mathrm{KOH} 25,04 \mathrm{~m}^{3} / \mathrm{s}$ ve $\mathrm{R}^{2}$ değeri 0,839

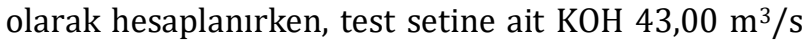
ve $R^{2}$ değeri ise 0,868 olarak bulunmuştur. Ayrıca, model 7'nin eğitim ve test setlerine ait saçlma diyagramları ile zaman serileri Şekil 3 ve Şekil 4'de gösterilmiştir. Şekil 3 ve 4'den görüldüğü gibi ölçülen değerler ile model sonuçları arasında iyi bir uyum olduğu ve noktaların 45 derecelik ideal uyum çizgisi etrafında toplandığı görülmüştür. Doğrusal eğilim çizgisi ile ideal uyum çizgileri arasındaki açının küçük olması da modelin başarısının yüksek olduğunu göstermektedir.

Tablo 2. Geliştirilen modellerin performansları

\begin{tabular}{|c|c|c|c|c|c|}
\hline \multirow[b]{2}{*}{$\begin{array}{l}\text { Model } \\
\text { no }\end{array}$} & \multirow[b]{2}{*}{ Model girdileri } & \multicolumn{2}{|c|}{ Ĕgitim seti } & \multicolumn{2}{|c|}{ Test seti } \\
\hline & & $\begin{array}{l}\mathrm{KOH} \\
\left(\mathrm{m}^{3} / \mathbf{s}\right) \\
\end{array}$ & $\mathbf{R}^{2}$ & $\begin{array}{l}\text { KOH } \\
\left(\mathrm{m}^{3} / \mathbf{s}\right) \\
\end{array}$ & $\mathbf{R}^{2}$ \\
\hline 1 & $\mathrm{Q}_{(1720) \mathrm{t}}$ & 42.02 & 0.546 & 84.45 & 0.492 \\
\hline 2 & $\mathrm{Q}_{(1720) \mathrm{t}}, \mathrm{Q}_{(1719) \mathrm{t}}$ & 42.16 & 0.543 & 86.58 & 0.466 \\
\hline 3 & $\mathrm{Q}_{(1720) \mathrm{t}} \mathrm{Q}_{(1719) \mathrm{t}} \mathrm{Q}_{(1712) \mathrm{t}}$ & 42.98 & 0.525 & 85.69 & 0.477 \\
\hline 4 & $\begin{array}{l}\mathrm{Q}_{(1720) \mathrm{t}} \mathrm{Q}_{(1719) \mathrm{t}} \mathrm{Q}_{(1712) \mathrm{t}} \\
\mathrm{Q}_{(1731) \mathrm{t}}\end{array}$ & 42.84 & 0.529 & 86.28 & 0.469 \\
\hline 5 & $\begin{array}{l}\mathrm{Q}_{(1720) \mathrm{t}} \mathrm{Q}_{(1719) \mathrm{t}} \mathrm{Q}_{(1712) \mathrm{t}} \\
\mathrm{Q}_{(1731) \mathrm{t}} \mathrm{Q}_{(1726) \mathrm{t}}\end{array}$ & 39.62 & 0.597 & 89.46 & 0.429 \\
\hline 6 & $\mathrm{Q}_{\mathrm{t}-1}$ & 25.27 & 0.836 & 44.01 & 0.862 \\
\hline 7 & $\mathrm{Q}_{\mathrm{t}-1}, \mathrm{Q}_{\mathrm{t}-2}$ & 25.04 & 0.839 & 43.00 & 0.868 \\
\hline 8 & $\mathrm{Q}_{\mathrm{t}-1}, \mathrm{Q}_{\mathrm{t}-2}, \mathrm{Q}_{\mathrm{t}-3}$ & 25.94 & 0.827 & 44.25 & 0.860 \\
\hline 9 & $\mathrm{Q}_{\mathrm{t}-1}, \mathrm{Q}_{\mathrm{t}-2}, \mathrm{Q}_{\mathrm{t}-3}, \mathrm{Q}_{\mathrm{t}-4}$ & 25.76 & 0.830 & 43.24 & 0.867 \\
\hline 10 & $\mathrm{Q}_{\mathrm{t}-1}, \mathrm{Q}_{\mathrm{t}-2}, \mathrm{Q}_{\mathrm{t}-3}, \mathrm{Q}_{\mathrm{t}-4}, \mathrm{Q}_{\mathrm{t}-5}$ & 22.09 & 0.875 & 47.99 & 0.836 \\
\hline
\end{tabular}



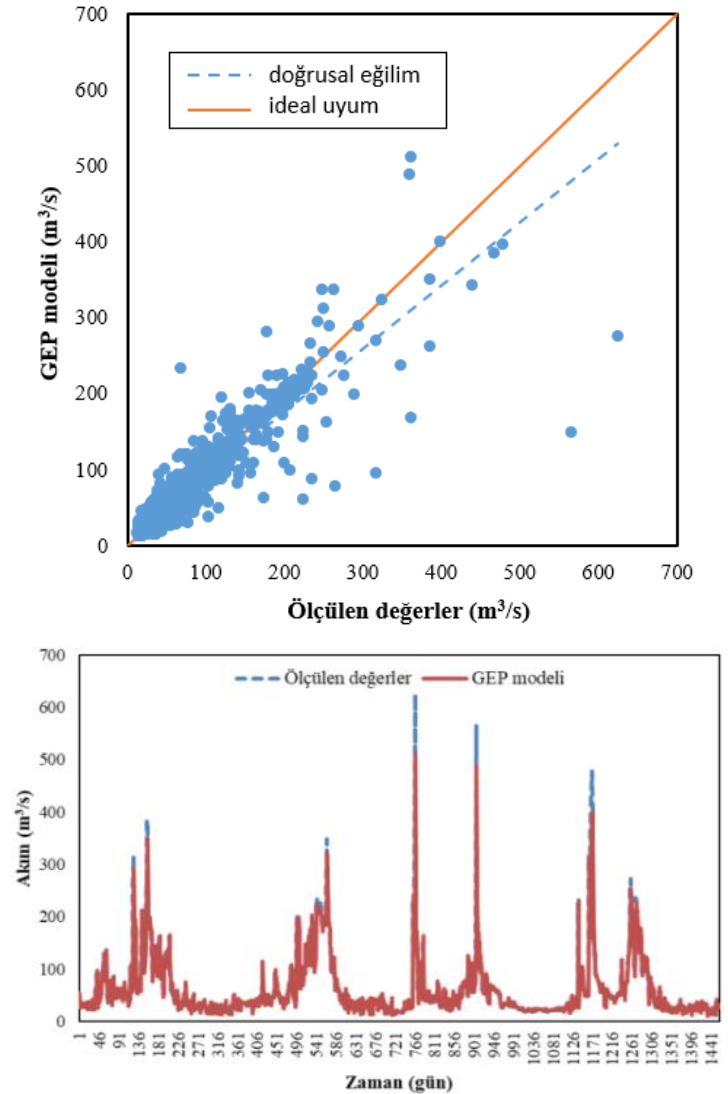

Şekil 3. Model 7'nin eğitim setine ait saçılma diyagramı ve
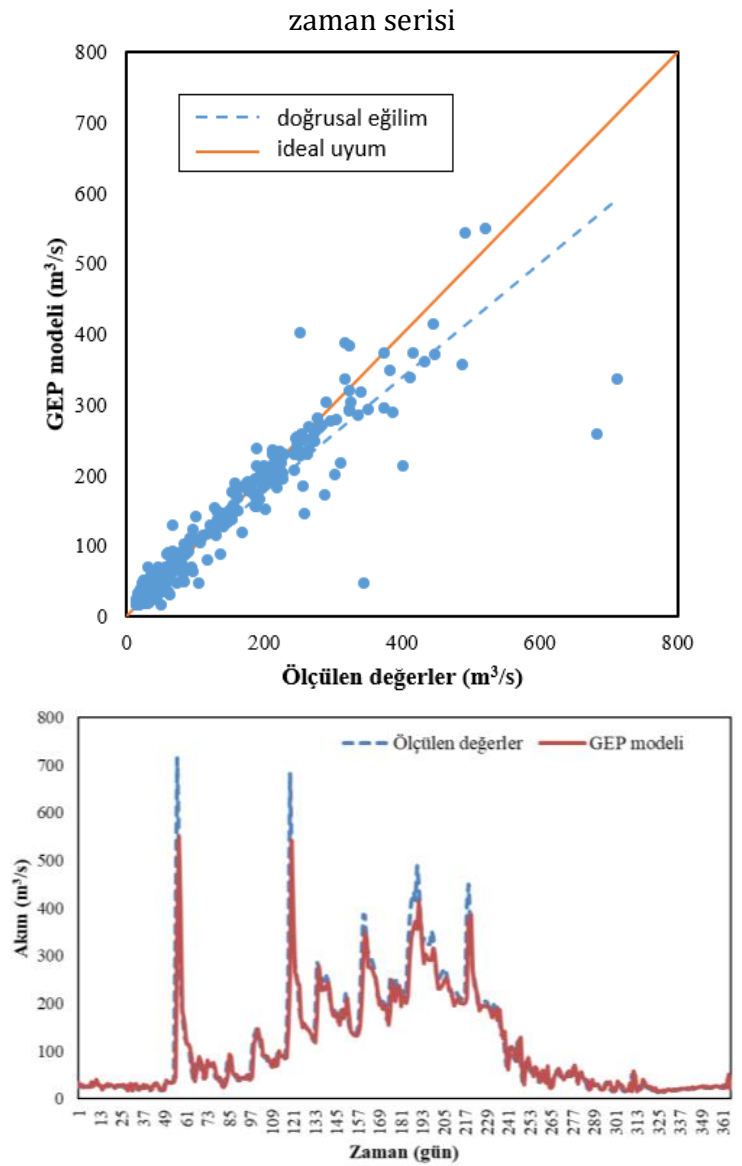

Şekil 4. Model 7'nin test setine ait saçılma diyagramı ve zaman serisi
Çalışmada elde edilen modellerden en uygun sonuçları veren model 7'ye ait matematiksel formül Eşitlik(1)'de verilmiştir. Bu modele ait olarak genetik kod kurallarına göre çıkarılan ifade ağacı ise Şekil 5'de gösterilmiştir. Formülde ve ifade ağacında yer alan Q sembolü Karahacılı istasyonunun t günündeki akım değerini, Q1 sembolü ( $\mathrm{t}-1$ ) günündeki akım değerini, Q2 sembolü ise ( $\mathrm{t}-2)$ günündeki akım değerini ifade etmektedir.

$$
\begin{aligned}
Q= & \left(\frac{\left(Q_{1}-Q_{2}\right)-\ln Q_{1}}{\frac{\sqrt{Q_{1}}}{\ln Q_{2}}}\right) \\
& +Q_{1}+\left(\sqrt{Q_{1}}-\left(\ln Q_{1}\right)^{\sqrt{\sqrt{Q_{1}}}}\right)
\end{aligned}
$$

Alt ifade ağacı 1
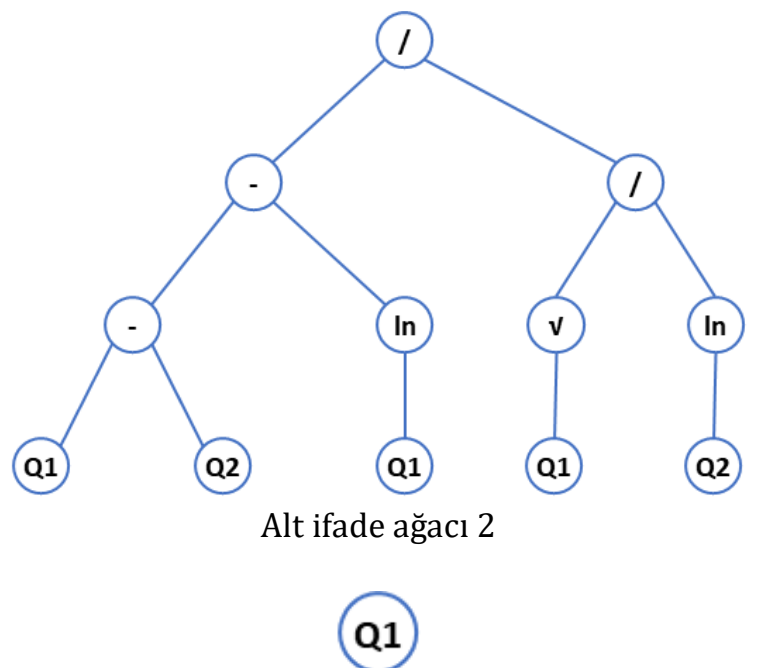

Alt ifade ağacı 3

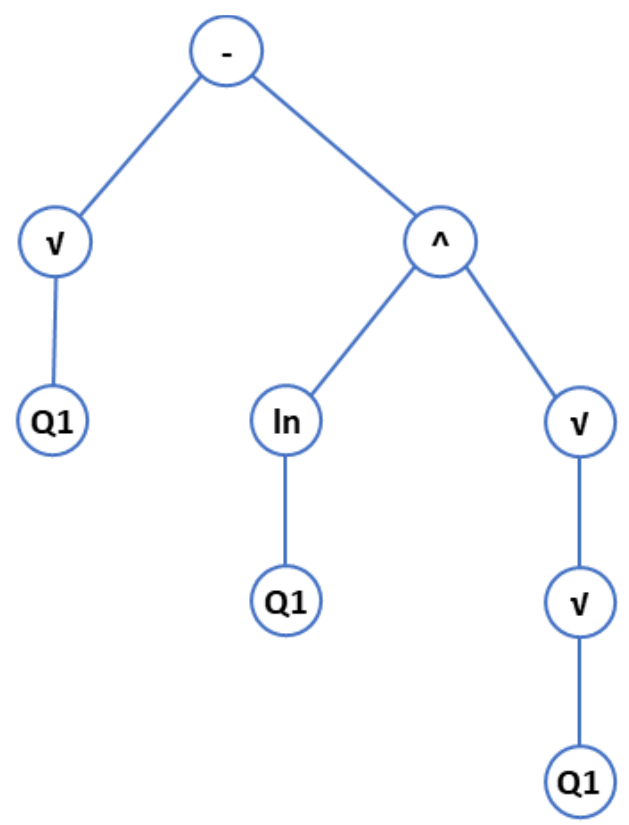

Şekil 5. Model 7'ye ait ifade ağacı 


\section{Sonuç ve Tartışma}

Bu çalışmada, Göksu Nehri'ne ait akım tahmini için gen ifade programlama (GEP) yöntemi ile çeşitli modeller geliștirilmiştir. Bu nehir üzerinde bulunan Karahacılı istasyonuna ait günlük akım tahmin modelleri geliştirmek için bu istasyonun önceki günlerine ait akım değerleri ve nehir üzerinde bulunan diğer beş adet akım gözlem istasyonunun akım değerleri kullanılmıştır. Önceki günlere ait değerler kullanılarak geliştirilen modellerin uygunluğu, diğer istasyonların değerleri kullanılarak geliştirilen modellere göre daha yüksek bulunmuştur. $\mathrm{Bu}$ modeller içerisinde, $\mathrm{Q}_{\mathrm{t}-1}$ ve $\mathrm{Q}_{\mathrm{t}-2}$ girdilerinin kullanıldığı modelde oldukça yüksek determinasyon katsayısı elde edilmiştir. Sonuç olarak, GEP yönteminin nehir akım tahmininde kullanılabilir olduğu görülmüştür. Ayrıca, GEP yöntemi ile geliştirilen modellerin matematiksel formüllerinin elde edilebiliyor olması, yeni veriler eklenmesi durumunda daha sonraki çalıșmalarda akım tahmininde büyük kolaylık sağlayacaktır.

\section{Teşekkür}

3026-YL-11 no.lu proje ile çalışmamı maddi olarak destekleyen SDÜ Araştırma Projeleri Yönetim Birimi'ne teşekkür ederiz.

\section{Conflict of Interest / Çıkar Çatışması}

Yazarlar tarafından herhangi bir çıkar çatışması beyan edilmemiştir.

No conflict of interest was declared by the authors.

\section{Kaynaklar}

Aytek, A., Kisi, O. 2008. A genetic programming approach to suspended sediment modelling. Journal of Hydrology, 351(3), 288-298.

Azamathulla, H. M., Ghani, A. A., Leow, C. S., Chang, C. K., Zakaria, N. A. 2011. Gene-expression programming for the development of a stagedischarge curve of the Pahang River. Water resources management, 25(11), 2901-2916.

Fernando, A. K., Shamseldin, A. Y., Abrahart, R. J. 2011. Use of gene expression programming for multimodel combination of rainfall-runoff models. Journal of Hydrologic Engineering, 17(9), 975985.

Ferreira, C. 2001. Gene expression programming: A new adaptive algorithm for solving problems. Complex Systems 13(2), 87-129.

Ferreira, C. 2006. Gene-expression programming: Mathematical modeling by an artificial intelligence. Springer-Verlag Berlin Heidelberg.

Goldberg, D.E. 1989. Genetic algorithms in search, optimization and machine learning. AddisonWesley.
Göksu (Kilikya). http://tr.wikipedia.org/ wiki/Göksu_(Kilikya) (Erişim Tarihi: 02.04.2017)

Grosan, C., Abraham, A. 2006. Evolving computer programs for knowledge discovery. International Journal of System Management 4(2), 7-24.

Kisi, O., Shiri, J., Tombul, M. 2013. Modeling rainfallrunoff process using soft computing techniques. Computers \& Geosciences, 51, 108117.

Koza, J.R. 1992. Genetic Programming: On the Programming of Computers by Means of Natural Selection, A Bradford Book The MIT Press Cambridge, Massachusetts London, England.

Nourani, V., Komasi, M., Alami, M. T. 2012. Hybrid wavelet-genetic programming approach to optimize ANN modeling of rainfall-runoff process. Journal of Hydrologic Engineering, 17(6), 724-741.

Shiri, J., Kisi, Ö. 2011. Comparison of genetic programming with neuro-fuzzy systems for predicting short-term water table depth fluctuations. Computers \& Geosciences, 37(10), 1692-1701.

Shiri, J., Sadraddini, A. A., Nazemi, A. H., Kisi, O., Landeras, G., Fard, A. F., Marti, P. 2014. Generalizability of Gene Expression Programming-based approaches for estimating daily reference evapotranspiration in coastal stations of Iran. Journal of hydrology, 508, 1-11.

Shoaib, M., Shamseldin, A. Y., Melville, B. W., Khan, M. M. 2015. Runoff forecasting using hybrid wavelet gene expression programming (WGEP) approach. Journal of Hydrology, 527, 326-344.

Traore, S., Guven, A. 2013. New algebraic formulations of evapotranspiration extracted from gene-expression programming in the tropical seasonally dry regions of West Africa. Irrigation Science, 31(1), 1-10.

Yılmaz, M.U. 2014. Performans Ağırlıklı Yöntemlerle Aylık Akımların Tahmini: Orta Fırat Havzası Uygulaması. İTÜ Fen Bilimleri Enstitüsü YL Tezi, $89 \mathrm{~s}$. 